\title{
Natural Organic Matter, Orthophosphate, pH, and Growth Phase Can Limit Copper Antimicrobial Efficacy for Legionella in Drinking Water
}

Yang Song, Amy Pruden, Marc A. Edwards,* and William J. Rhoads*

Cite This: Environ. Sci. Technol. 2021, 55, 1759-1768

Read Online

ACCESS | Lلll Metrics \& More | 国 Article Recommendations ｜ sl Supporting Information

ABSTRACT: Copper $(\mathrm{Cu})$ is a promising antimicrobial for premise plumbing, where ions can be dosed directly via copper silver ionization or released naturally via corrosion of $\mathrm{Cu}$ pipes, but $\mathrm{Cu}$ sometimes inhibits and other times stimulates Legionella growth. Our overarching hypothesis was that water chemistry and growth phase control the net effect of $\mathrm{Cu}$ on Legionella. The combined effects of $\mathrm{pH}$, phosphate concentration, and natural organic matter (NOM) were comprehensively examined over a range of conditions relevant to drinking water in bench-scale pure culture experiments, illuminating the effects of $\mathrm{Cu}$ speciation and precipitation. It was found that cupric ions $\left(\mathrm{Cu}^{2+}\right)$ were drastically reduced at $\mathrm{pH}>7.0$ or in the presence of ligand-forming phosphates or NOM. Further, exponential phase L. pneumophila were

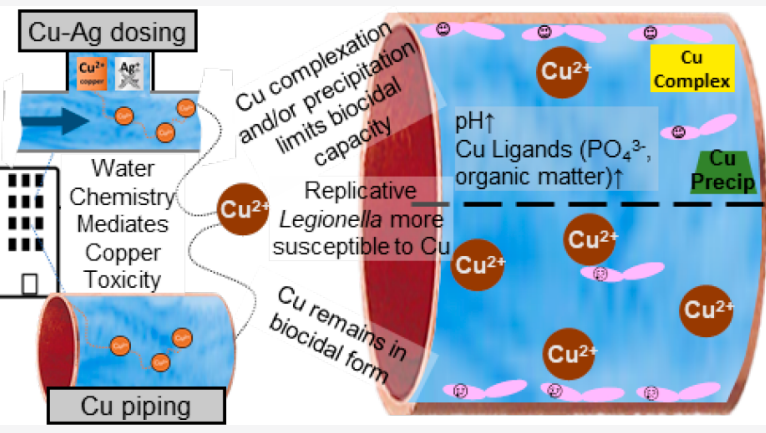
$2.5 \times$ more susceptible to $\mathrm{Cu}$ toxicity relative to early stationary phase cultures. While $\mathrm{Cu}^{2+}$ ion was the most effective biocidal form of $\mathrm{Cu}$, other inorganic ligands also had some biocidal impacts. A comparison of 33 large drinking water utilities' field-data from 1990 and 2018 showed that $\mathrm{Cu}^{2+}$ levels likely decreased more dramatically $(>10 \times)$ than did the total or soluble Cu $(2 \times)$ over recent decades. The overall findings aid in improving the efficacy of $\mathrm{Cu}$ as an actively dosed or passively released antimicrobial against $L$. pneumophila.

KEYWORDS: copper, Legionella pneumophila, corrosion control, natural organic matter, premise plumbing

\section{INTRODUCTION}

With a $>500 \%$ increase in reported incidence in the U.S. over the last 20 years, Legionnaires' disease increasingly burdens building owners and operators who seek its control. Water management programs provide broad guidelines on how to ensure the safety of a given building's water, ${ }^{1}$ and specific strategies depend on the technology applied, local laws and code, water quality parameters, and building-level treatment and operation. $^{2-4}$ Selecting pipe materials that are less amenable to Legionella growth is one avenue of interest. In particular, copper $(\mathrm{Cu})$ pipes can exert natural biocidal properties when $\mathrm{Cu}$ is released via corrosion. Intentionally dosing $\mathrm{Cu}$ ions via $\mathrm{Cu}$-silver ionization (CSI) systems is also a common on-site disinfection technology for large institutional buildings. ${ }^{5-8}$ However, conflicting efficacies of both $\mathrm{Cu}$ pipes and CSI systems in controlling Legionella growth have been reported. ${ }^{7,9-12}$

The main biocidal form of $\mathrm{Cu}$ is believed to be cupric ion $\left(\mathrm{Cu}^{2+}\right),{ }^{13}$ which interacts with negatively charged cell membranes and causes cell lysis. ${ }^{5}$ In many drinking waters, $\mathrm{Cu}^{2+}$ concentrations are expected to be relatively low and strongly influenced by water chemistry. However, little research has been carried out to establish the practical range of water chemistry parameters that ensure efficacy of $\mathrm{Cu}$ as a biocide in building water systems. Monitoring plans for CSI systems tend to focus mainly on maintaining total $\mathrm{Cu}$ levels in the range of $200-800 \mu \mathrm{g} / \mathrm{L}$ and do not consider soluble $\mathrm{Cu}$ or $\mathrm{Cu}^{2+}$ ions. ${ }^{3,14-16}$ The negative impacts of elevated $\mathrm{pH}$ on the biocidal capacity of $\mathrm{Cu}$ toward Legionella have been reported, ${ }^{10}$ but only at the extremes of typical drinking water system $\mathrm{pH}$ (7 vs 9). A higher resolution examination of $\mathrm{pH}$ effects between these two extremes, and considerate of other potential mediating factors, is needed.

Other water chemistry attributes that are likely to influence $\mathrm{Cu}$ corrosion, speciation, and bioavailability in tap water are also important to consider. The use of phosphate-based corrosion inhibitors has increased nationally over the last 20 years and is likely to reduce the toxic effects of $\mathrm{Cu}$ on Legionella based on existing knowledge of cuprosolvency and speciation. ${ }^{17,18}$ However, to our knowledge, this has never

Received: October 9, 2020

Revised: December 13, 2020

Accepted: December 16, 2020

Published: January 11, 2021

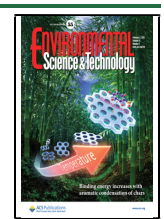


been demonstrated or studied. In addition, baseline levels of natural organic matter (NOM) have been increasing in some U.S. source waters as an indirect consequence of climate change, land use alteration, and improved sulfur and nitrogen air pollution controls under the Clean Air Act, ${ }^{19,20}$ which might also be decreasing $\mathrm{Cu}$ bioavailability in potable water systems. $^{21-24}$

The physiological state of Legionella is also important to consider in evaluating the efficacy of $\mathrm{Cu}$ disinfection. Within host amoeba cells, Legionella are typically viewed as being in a replicative state, which is simulated in pure culture experiments by the exponential growth phase. However, the stationary growth phase of Legionella, which can be induced by starvation and environmental stress, is thought to be more resistant to $\mathrm{Cu}^{25}$ The stationary growth phase, the stage entered after Legionella are released from the host organism, is also thought to be more relevant to Legionella transmissivity (i.e., virulence). However, previous work regarding the efficacy of $\mathrm{Cu}$ as a biocide focused on Legionella generated from nascent colonies grown on agar media (i.e., plate scrapes), ${ }^{16}$ which contains a mixture of growth phases and, without other pretreatment steps, consists largely of exponential phase cells or an unknown mixture of exponential and stationary cells. More recent work has demonstrated that strain dependency results in a 4-fold difference in susceptibility, ${ }^{26}$ but, to our knowledge, the impact of the physiological state of Legionella on the biocidal capacity of $\mathrm{Cu}$ has not been explicitly investigated.

Here, we provide an integrated and comprehensive examination of the impact of key water chemistry factors on $\mathrm{Cu}$ speciation and precipitation on the culturability of $L$. pneumophila in bench-scale experiments. We determine the impact of $\mathrm{pH}$, levels of orthophosphate corrosion inhibitor, and NOM on the levels of total, soluble, and $\mathrm{Cu}^{2+}$ ions in a simulated drinking water environment and investigate their resulting impact on exponential and stationary-phase Legionella. The results are contextualized with respect to trends in comparable field-data to improve guidance on the effective application of $\mathrm{Cu}$ as a Legionella control measure.

\section{MATERIALS AND METHODS}

Test Water, Reagents, and Glassware. To represent a realistic background drinking water matrix for this and future studies, Blacksburg, VA tap water was used as the base water for all experiments. Blacksburg tap water was passed through three filters in sequence for use in all experiments: (1) ferric oxide column (Brightwell Aquatics), which removed municipally supplied phosphate-based corrosion inhibitor and some NOM; (2) granular activated carbon (GAC), which removed chlorine and additional NOM; and (3) a $0.22 \mu \mathrm{m}$ pore size mixed cellulose ester filter (MilliporeSigma) to remove particles and microorganisms. Afterward, the base water had $<0.05 \mathrm{mg} / \mathrm{L}$ total chlorine ( $>98.3 \%$ removal), $<10 \mu \mathrm{g} / \mathrm{L}$ phosphorus ( $>97.5 \%$ removal), and $<0.5 \mathrm{mg} / \mathrm{L}$ organic matter (Table S1). This water was autoclaved at $121{ }^{\circ} \mathrm{C}$ for $15 \mathrm{~min}$. Glassware was used as a nonreactive, inert material to conduct all experiments. All glassware used was soaked in $10 \%$ nitric acid for $24 \mathrm{~h}$, rinsed with reverse osmosis water, and autoclaved. All experiments were carried out at $37{ }^{\circ} \mathrm{C}$ in a walk-in incubator (Thermmax, Warminster, PA) to mimic worst-case portions of building water plumbing systems (bottom of electric water heaters, ${ }^{27}$ convectively mixed distal taps $^{28}$ or tempered water after mixing valves) and eliminate temperature as a factor that may negatively impact Legionella culturability. $\mathrm{pH}$ was adjusted with $0.2 \mathrm{~N}$ sulfuric acid or $0.1 \mathrm{~N}$ potassium hydroxide. $\mathrm{Cu}$ stock solutions of $100 \mathrm{mg} / \mathrm{L} \mathrm{Cu}$ as $\mathrm{CuSO}_{4}$ (Sigma-Aldrich, St. Louis, MO) were freshly prepared and adjusted to $\mathrm{pH}=4.0 \pm 0.05$ to maintain $\mathrm{Cu}$ solubility. Orthophosphate stock solutions were prepared by adding 9.52 $\mathrm{g} / \mathrm{L}$ monobasic dihydrogen phosphate and $5.92 \mathrm{~g} / \mathrm{L}$ dibasic monohydrogen phosphate targeting a solution with $\mathrm{pH}=7.0$. As per convention in water treatment, the summation of orthophosphate components $\left(\mathrm{PO}_{4}{ }^{3-}, \mathrm{HPO}_{4}{ }^{2-}\right.$, and $\left.\mathrm{H}_{2} \mathrm{PO}_{4}{ }^{-}\right)$is noted in units "as $\mathrm{PO}_{4}{ }^{3-}$ " in the main text. Two NOM stock solutions were prepared from cleaned humic acid (HA) (Sigma-Aldrich) solutions after sequential alkalinization and acidification to remove impurities ${ }^{29}$ or Suwannee River II fulvic acid (FA) (Standard FA, International Humic Substance Society).

Kinetics of Copper Precipitation. Cu precipitation tests were performed in batch reactors (Figure S1). Base water was dosed with $0,30,300$, and $1000 \mu \mathrm{g} / \mathrm{L} \mathrm{Cu}$, and the $\mathrm{pH}$ was adjusted to $7.0,7.5,8.0$, or 8.5 ( $\pm 0.05 \mathrm{pH}$ units). Total and soluble $\mathrm{Cu}, \mathrm{Cu}^{2+}$ ions, and $\mathrm{pH}$ were measured initially in the base water, then immediately aliquoted to $50 \mathrm{~mL}$ glass reactors and capped without any headspace, which limited $\mathrm{pH}$ drift due to gas transfer. Reactors were sacrificed for sampling at $t=10$, $20,30,40,50,60,120$, and $240 \mathrm{~min}$. Control groups (with no $\mathrm{Cu}$ dosed) were confirmed to contain $\mathrm{Cu}<10 \mu \mathrm{g} / \mathrm{L}$ as background throughout the experiments.

Copper Speciation. The impact of $\mathrm{pH}$ and ligands on $\mathrm{Cu}$ speciation was evaluated in experiments set up in the same manner as the precipitation tests (Figure S2) in triplicate. When we analyzed the $\mathrm{pH}$ impact, $\mathrm{Cu}$ was added to achieve a final concentration of $1000 \mu \mathrm{g} / \mathrm{L} \mathrm{Cu}$ to base water at the target $\mathrm{pH}$. When we analyzed the impact of $\mathrm{Cu}$ ligands, orthophosphate (at 0.5 and $1 \mathrm{mg} / \mathrm{L}$ orthophosphate as $\mathrm{PO}_{4}{ }^{3-}$ ) or NOM (2 and $5 \mathrm{mg} / \mathrm{L} \mathrm{HA}$ and $\mathrm{FA}$ as total organic carbon; TOC) was added to base water with $\mathrm{pH}=7.0 \pm 0.02$, followed by $\mathrm{Cu}$ dosing at $1000 \mu \mathrm{g} / \mathrm{L}$ and $\mathrm{pH}$ readjustment to $7.0 \pm 0.02$. This $\mathrm{pH}$ was selected to represent the lowest end of the typical $\mathrm{pH}$ range for water utilities and maximize the concentration of $\mathrm{Cu}^{2+}$. Biological replicates were obtained by repeating this process three times for every condition.

Water Chemistry Measurements. $\mathrm{pH}$ was measured with an Oakton (Vernon Hills, IL) portable $\mathrm{pH}$ meter with automatic temperature correction and was calibrated before each experiment and every $2 \mathrm{~h}$ during experiments. Total $\mathrm{Cu}$ samples were prepared by transferring $10 \mathrm{~mL}$ solutions from sacrificial reactors, after mixing by inverting, into sterile tubes (Evergreen, Buffalo, NY). Soluble $\mathrm{Cu}$ was operationally defined by filtration through a $0.45 \mu \mathrm{m}$ pore size nylon syringe filter (Whatman, GE Healthcare, Pittsburgh, PA). Both total $\mathrm{Cu}$ and soluble $\mathrm{Cu}$ samples were acidified with nitric acid (2\% vol/vol) and initially measured by both inductively coupled plasma mass spectrometry (ICP-MS) and spectrophotometry with $\mathrm{HACH} \mathrm{Cu} \mathrm{Verl} \mathrm{reagents} \mathrm{(method} \mathrm{8506,} \mathrm{Hach,}$ Loveland, $\mathrm{CO}$ ) for a range of experimental conditions. Because the results of both methods were in good agreement (Figure S3), the colorimetric method was used to check concentrations during the experimental runs, and one of three replicates were cross-checked with the ICP-MS for QA/QC. $\mathrm{Cu}^{2+}$ were measured by an ion selective electrode (Cole-Parmer, Vernon Hills, IL) following instructions provided by the manufacturer with $50 \mathrm{~mL}$ samples predosed with $1 \mathrm{~mL}$ of ionic strength adjustment (ISA) solution ( $5 \mathrm{~N} \mathrm{NaNO}_{3}$ ). The ion selective electrode was checked every $2 \mathrm{~h}$ for calibration drift using 


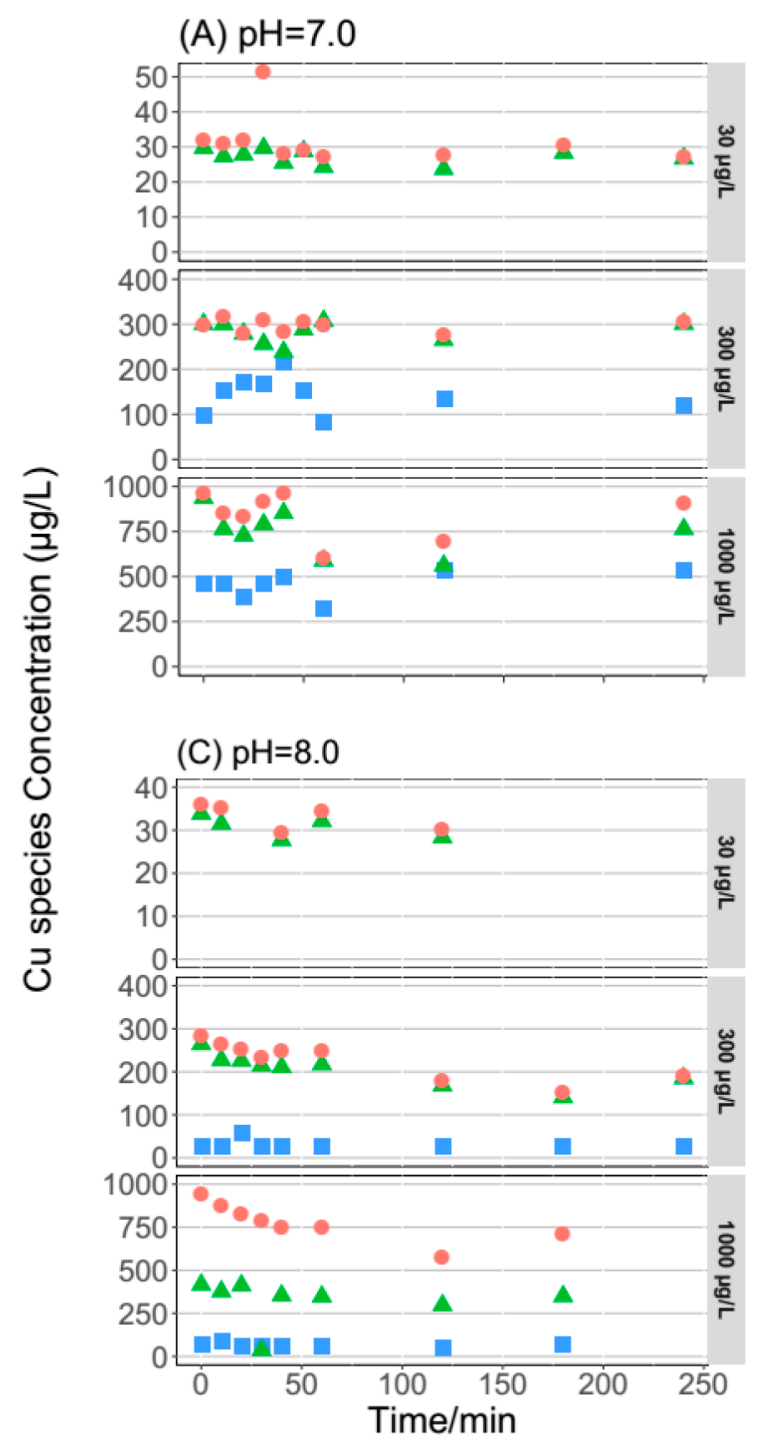

(B) $\mathrm{pH}=7.5$

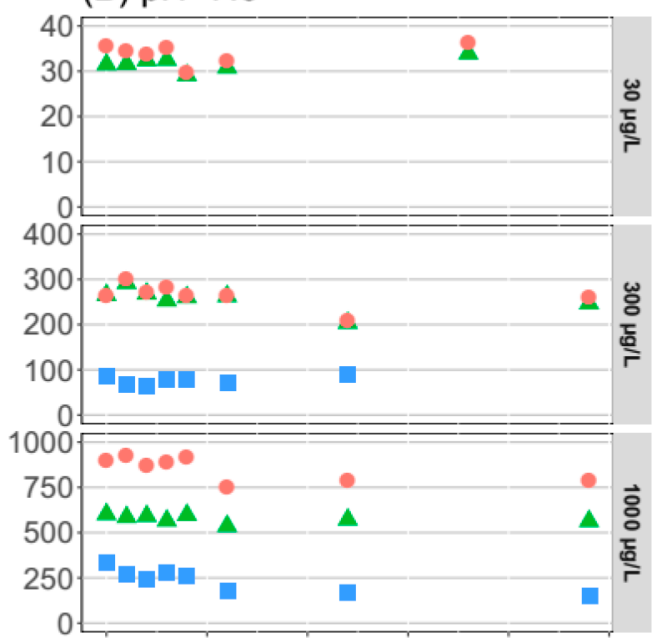

(D) $\mathrm{pH}=8.5$

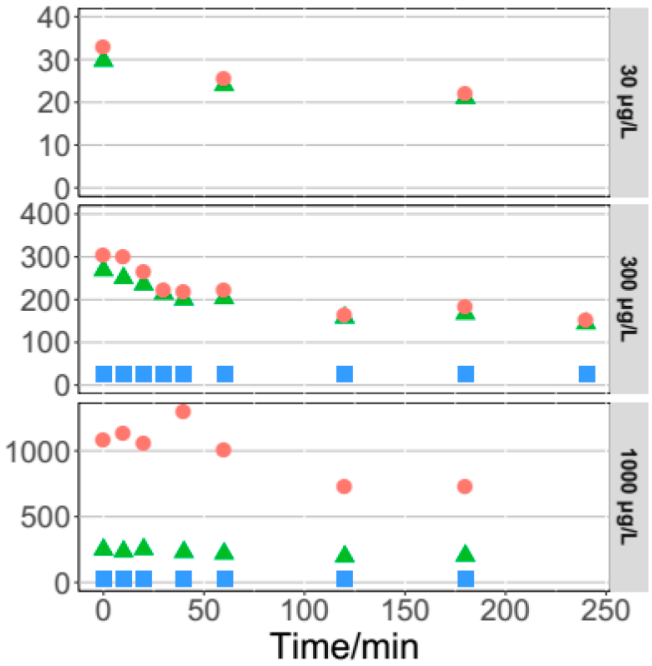

Figure 1. $\mathrm{Cu}$ species (total $\mathrm{Cu}$, soluble $\mathrm{Cu}$, and $\mathrm{Cu}^{2+}$ ) concentration as a function of time at $\mathrm{pH}$ values of 7.0, 7.5, 8.0, and 8.5. Cu ${ }^{2+}$ levels at total $\mathrm{Cu}=30 \mu \mathrm{g} / \mathrm{L}$ are not shown because they are below the probe quantification limit of $50 \mu \mathrm{g} / \mathrm{L}$. For other conditions, $\mathrm{Cu}^{2+}$ measurements $<50 \mu \mathrm{g} / \mathrm{L}$ are plotted as $25 \mu \mathrm{g} / \mathrm{L}$ for visualization purposes.

methods recommended by the manufacturer (Cole-Parmer ${ }^{30}$ ), with a limit of quantification of $50 \mu \mathrm{g} / \mathrm{L}$. Relative standard deviation (RSD) of the ion selective electrode was determined with 10 individual tests as $<20 \%$ variation when total $\mathrm{Cu}>100$ $\mu \mathrm{g} / \mathrm{L}$ and over $50 \%$ when total $\mathrm{Cu}<50 \mu \mathrm{g} / \mathrm{L}$ (Figure S4).

L. pneumophila Cultivation Experiments. Bacterial Culture Preparation. L. pneumophila cultures were freshly prepared for each experimental run. L. pneumophila serogroup 1 strain 130b was obtained from the U.S. Centers for Disease Control and stored at $-80{ }^{\circ} \mathrm{C}$ in buffered yeast extract (BYE) broth ( $10 \mathrm{~g}$ of ACES, $10 \mathrm{~g}$ of yeast extract, $1 \mathrm{~g}$ of $\alpha$-ketoglutaric acid, $0.4 \mathrm{~g}$ of L-cysteine, and $0.25 \mathrm{~g}$ of ferric pyrophosphate per litter) with glycerol (20\% vol/vol). Frozen stocks were isolated onto buffered charcoal-yeast extract (BCYE) agar plates (12 g of agar, $2 \mathrm{~g}$ of activated charcoal, $1 \mathrm{~g}$ of $\alpha$-ketoglutarate monopotassium, $10 \mathrm{~g}$ of ACES buffer, $2.8 \mathrm{~g}$ of potassium hydroxide, $0.25 \mathrm{~g}$ of iron pyrophosphate, $3 \mathrm{~g}$ of ammoniumfree glycine, $80000 \mathrm{IU}$ polymyxin B sulfate, $0.001 \mathrm{~g}$ of vancomycin hydrochloride, $0.08 \mathrm{~g}$ of cycloheximide, and $0.4 \mathrm{~g}$ of L-cysteine monohydrate per liter) and incubated for $72 \mathrm{~h}$ at $37{ }^{\circ} \mathrm{C}$. BYE broth was inoculated with L. pneumophila at an initial optical density at wavelength of $600 \mathrm{~nm}\left(\mathrm{OD}_{600}\right)$ of 0.2 (Implen) by transferring $1 \mathrm{~mL}$ of sterile BYE broth onto $\mathrm{t}$ streaked culture plates and harvesting colonies with a $3 \times$ flame-sterilized glass cell spreader. Inoculated BYE broth was incubated at $37{ }^{\circ} \mathrm{C}$ with agitation for either $9 \mathrm{~h}$ (exponential phase) or $14 \mathrm{~h}$ (early stationary phase), as determined by $\mathrm{OD}_{600}$ growth curves (Figure S5). After broth culture, cells were pelleted by centrifuging at $5000 \mathrm{~g}$ for $10 \mathrm{~min}$, and the supernatant was decanted. Cell pellets were washed twice with $10 \mathrm{~mL}$ of base water, resuspended in $2 \mathrm{~mL}$ of base water, and diluted to $\sim 3 \times 10^{8}$ colony forming units $(\mathrm{CFU}) / \mathrm{mL}$ (McFarland Standard No. 1, $\left.\mathrm{OD}_{600}=0.257\right) .{ }^{31}$ Subsequently, $\sim 3 \times 10^{6} \mathrm{CFU} / \mathrm{mL}$ dilutions were used for each experimental run.

Copper Inactivation Tests. $\mathrm{Cu}$ inactivation test procedures were similar to those of the $\mathrm{Cu}$ speciation tests (Figure S6). All $\mathrm{Cu}$ inactivation tests were performed at an initial total $\mathrm{Cu}$ of 
$800 \mu \mathrm{g} / \mathrm{L}$, unless otherwise stated, which represents the upper limit of recommended copper ion levels for copper inactivation. ${ }^{9,10,16}$ After $\mathrm{Cu}$ dosing, ligand addition (at $\mathrm{pH} 7$ only; none, $0.5,3 \mathrm{mg} / \mathrm{L}$ phosphate as $\mathrm{PO}_{4}{ }^{3-}$, or $\mathrm{NOM}=5 \mathrm{mg} /$ $\mathrm{L}$ as TOC), $\mathrm{pH}$ adjustment (7.0, 7.5, 8.0, or 8.5), and mixing for $20 \mathrm{~min}$ to allow $\mathrm{Cu}$ speciation to stabilize (based on the solubility and speciation experiential results), glass bottles were moved to a biosafety cabinet to inoculate L. pneumophila. After being mixed, initial L. pneumophila levels were quantified as described below, and solutions were transferred to sterile 50 $\mathrm{mL}$ sacrificial glass reactors and incubated at $37{ }^{\circ} \mathrm{C}$. Reactors were inverted to mix and sacrificed to quantify culturable $L$. pneumophila, targeting time points of $t=10,20,30,40,50,60$, 120, 240, and $360 \mathrm{~min}$. All $\mathrm{Cu}$ inactivation data were fitted with Chick-Watson first-order inactivation curves, and the disinfection constants were estimated by best-fitted lines using the least-squares method. Biological replicates were obtained by repeating this process three times for every condition. At least one control representing background chemistry conditions and growth phases, without copper, was operated for each condition. For controls in $\mathrm{Cu}$ inactivation tests using early stationary phase L. pneumophila, in total 13 replicates ( 3 from $\mathrm{pH}=7$ and $8.5 ; 2$ from $\mathrm{PO}_{4}{ }^{3-}=3 \mathrm{mg} / \mathrm{L}$ and $\mathrm{NOM}=5 \mathrm{mg} / \mathrm{L}$; and 1 from $\mathrm{pH}=7.5,8$, and $\mathrm{PO}_{4}{ }^{3-}=0.5 \mathrm{mg} / \mathrm{L}$ ) showed negligible reduction in L. pneumophila with time, and therefore controls were combined across experiments for statistical comparison.

L. pneumophila Enumeration. One milliliter of solution was transferred to sterile tubes predosed with EDTA (molar ratio of EDTA: $\mathrm{Cu}=5: 1$ ) to complex $\mathrm{Cu}$. We confirmed that EDTA had no impact on the culturability of L. pneumophila in our experiments. Serial dilutions $\left(1: 10-1: 10^{5}\right)$ were prepared with base water, and $10 \mu \mathrm{L}$ was transferred onto BCYE+GVCP agar plates using a multichannel pipet in triplicate (Figure S6). Only dilutions with 3-30 distinct L. pneumophila colonies were considered quantifiable. The lower limit of detection (LOD) (1 CFU counted) and limit of quantification (LOQ) (3 CFUs counted) of the serial dilution plating method were 100 and $300 \mathrm{CFU} / \mathrm{mL}$, respectively, when $10 \mu \mathrm{L}$ was plated. Where the number of CFUs was expected to be few, $100 \mu \mathrm{L}$ was also directly spread plated to further lower the LOD and LOQ to 10 and $200 \mathrm{CFU} / \mathrm{mL}$, respectively (i.e., 1 colony and 20 colonies observed). After being dried in the biosafety cabinet, plates were incubated at $37{ }^{\circ} \mathrm{C}$ and enumerated after $72 \mathrm{~h}$.

Drinking Water Utilities Field-Data Analyses. Thirtythree large drinking water utilities were selected from a 1990 systematic survey of drinking water utilities ${ }^{32}$ to be representative of their corrosion control methods (no corrosion control, $\mathrm{pH}$ control, inhibitor control, and both controls). Most recent (2018) customer confidence reports of the 33 utilities were utilized to extract data for $90 \%$ total $\mathrm{Cu}$, $\mathrm{pH}$, phosphate, and alkalinity. A subset of 11 utilities that contain all needed information were utilized to predict changes in $\mathrm{Cu}$ speciation in drinking water systems in the U.S. using equilibrium models.

Statistical Analyses. Statistical differences in $\mathrm{Cu}$ speciation and $\mathrm{Cu}$ inactivation data were determined using ANOVA with post hoc Tukey's Test or Kruskal-Wallis test with post hoc Dunn's Test (Bonferroni correction) in R (version 3.4.3). The summary statistics (mean, standard deviation) and statistical difference for left-censored (below LOQ or LOD) data sets were calculated using regression on order statistics
(ROS) and maximum likelihood estimation (MLE) regression test $^{33}$ in R (version 3.4.3). Significance threshold was set at $P$ $\leq 0.05$. Calculations and graphs were generated using $\mathrm{R}$ (version 3.4.3) and Microsoft Excel 2016 (Microsoft). Thermodynamic equilibrium models were generated using MINEQL+ (version 4.6).

\section{RESULTS AND DISCUSSION}

Changes in $\mathrm{Cu}$ speciation and precipitation in laboratory tests are reported first, followed by experiments quantifying the impact of these changes on the toxicity of $\mathrm{Cu}$ to Legionella. Finally, a systematic comparison of publicly available $\mathrm{Cu}$ monitoring data and predicted changes in the presence of toxic forms of $\mathrm{Cu}$ in drinking water systems in the U.S. using equilibrium models is reported.

Copper Speciation and Solubility Experiments. Copper Stability. Water was dosed with $\mathrm{Cu}$ at 30,300, or $1000 \mu \mathrm{g} / \mathrm{L}$ at $\mathrm{pH}$ of $7.0,7.5,8.0$, or 8.5 to examine precipitation and speciation kinetics (Figure $\mathrm{S} 1$ ). $\mathrm{Cu}$ species (total, soluble, and $\mathrm{Cu}^{2+}$ ) generally reached short-term equilibrium after $20 \mathrm{~min}$ of incubation (Figure 1). The mean $\mathrm{pH}$ value after incubation was $7.02 \pm 0.08,7.42 \pm 0.08,7.82 \pm$ 0.10 , and $8.26 \pm 0.14$ for the targeted $\mathrm{pH}=7.0,7.5,8.0$, and 8.5 conditions, respectively, reflecting slight naturally occurring $\mathrm{pH}$ shifts. $\mathrm{Cu}$ did not significantly $(<2 \%)$ precipitate at the lower doses of 30 and $300 \mu \mathrm{g} / \mathrm{L}$ at any $\mathrm{pH}$ level. At $1000 \mu \mathrm{g} / \mathrm{L}$, more $\mathrm{Cu}$ precipitated (i.e., less soluble $\mathrm{Cu}$ was measured) at the higher $\mathrm{pH}$, as would be predicted on the basis of solubility (Figure 2A). For instance, soluble $\mathrm{Cu}$ was $87.2 \%$ of total $\mathrm{Cu}$ at $\mathrm{pH} 7.0$ and decreased to $68.7 \%$ at $\mathrm{pH} 7.5,41.4 \%$ at $\mathrm{pH} 8.0$, and $23.7 \%$ at $\mathrm{pH}$ 8.5. The level of $\mathrm{Cu}^{2+}$ ions decreased even more dramatically as the $\mathrm{pH}$ increased. At a dose of $300 \mu \mathrm{g} / \mathrm{L}$ $\mathrm{Cu}$ at $\mathrm{pH} 7.0,50.8 \%$ of the $\mathrm{Cu}$ was present in the form of $\mathrm{Cu}^{2+}$, dropping to $<11.7 \%$ at $\mathrm{pH} 8.5$. A similar trend was observed at a $\mathrm{Cu}$ dose of $1000 \mu \mathrm{g} / \mathrm{L}$ (Figure 2B).

Copper Speciation. The presence of $\mathrm{Cu}$ ligand-forming components reduced the solubility and/or level of $\mathrm{Cu}^{2+}$. The addition of $2-5 \mathrm{mg} / \mathrm{L}$ humic acid or fulvic acid (as TOC) produced $<50 \mu \mathrm{g} / \mathrm{L}$ of $\mathrm{Cu}^{2+}$ and completely prevented precipitation (Figure 3). The condition with $5 \mathrm{mg} / \mathrm{L} \mathrm{HA}$ was utilized for further $\mathrm{Cu}$ inactivation experiments. At 1000 $\mu \mathrm{g} / \mathrm{L}$, the addition of just $0.5 \mathrm{mg} / \mathrm{L} \mathrm{PO}_{4}{ }^{3-}$ as orthophosphate at $\mathrm{pH} 7$ reduced soluble $\mathrm{Cu}$ from $813.8 \mu \mathrm{g} / \mathrm{L}(89.1 \%$ of total $\mathrm{Cu})$ without $\mathrm{PO}_{4}{ }^{3-}$ to $407.8 \mu \mathrm{g} / \mathrm{L}(48.6 \%$ of total $\mathrm{Cu})$ and reduced $\mathrm{Cu}^{2+}$ from $52.9 \%$ down to $6.1 \%$ (Figure 3 ). These observed soluble and $\mathrm{Cu}^{2+}$ levels were generally greater than those predicted by chemical equilibrium models, consistent with the short-term nature of the tests (hours) relative to the anticipated time to reach copper equilibrium conditions (days to weeks). This could be interpreted as a potential benefit to application of CSI systems, because the lower levels of copper predicted by complexation and precipitation did not occur.

Impact of $\mathrm{Cu}$ on L. pneumophila Culturability. Exponential versus Stationary Phase. Exponential phase L. pneumophila cultures were 2.5 times more susceptible to $\mathrm{Cu}$ relative to early stationary phase cultures (Figure 4). In 120 min, $800 \mu \mathrm{g} / \mathrm{L}$ total $\mathrm{Cu}$ at $\mathrm{pH}=7.0$ caused complete loss of detectable CFUs $(\sim 4.5-\log$ reduction) relative to a 1.8 -log reduction in CFUs for early stationary phase L. pneumophila. Control groups (no $\mathrm{Cu}$ dose) decreased $<0.3 \log \mathrm{CFU} / \mathrm{mL}$ in both the exponential phase (180 min test) and the early stationary phase (360 min test). Lin et al. showed that $800 \mu \mathrm{g} /$ $\mathrm{L} \mathrm{Cu}$ was able to reduce L. pneumophila in DI water by over 6 


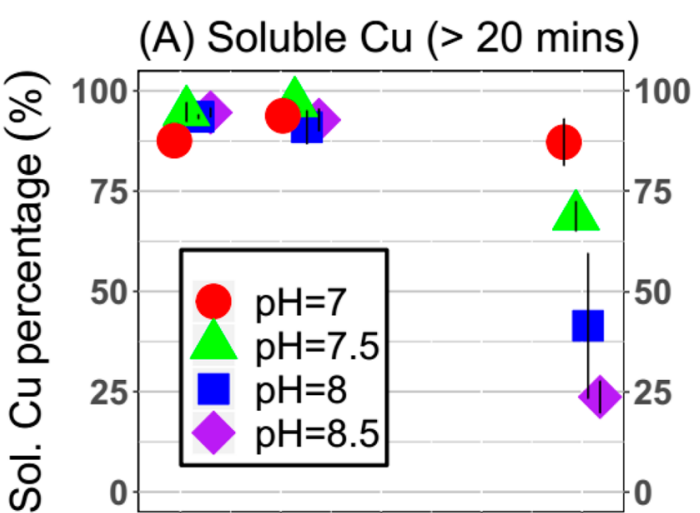

(B) $\mathrm{Cu}^{2+}(>20$ mins $)$

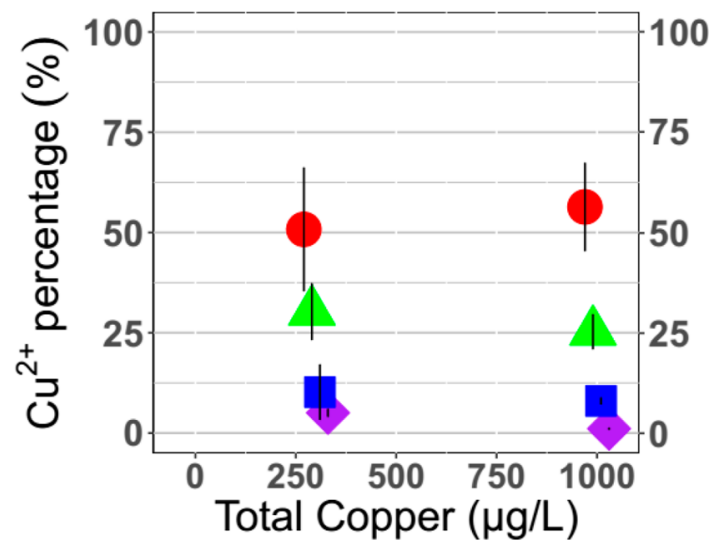

Figure 2. Steady-state percentage of $\mathrm{Cu}$ measured at $20-240 \mathrm{~min}$ as (A) average soluble $\mathrm{Cu}$ and (B) average $\mathrm{Cu}^{2+}$. All data points represent the average of all data collected after $20 \mathrm{~min}$ of incubation; error bars represent standard deviation. $n \geq 3$ (median $=6$ ) for each data point. $\mathrm{Cu}^{2+}$ levels at total $\mathrm{Cu}=30 \mu \mathrm{g} / \mathrm{L}$ are not shown because it is below the $\mathrm{Cu}^{2+}$ probe quantification limit of $50 \mu \mathrm{g} / \mathrm{L}$. Because a substantial portion of the data was censored $\left(\mathrm{Cu}^{2+}<50 \mu \mathrm{g} / \mathrm{L}\right)$ in the $\mathrm{Cu}=300 \mu \mathrm{g} / \mathrm{L}$ condition at $\mathrm{pH}=8$ and 8.5 , as well as $\mathrm{Cu}=1000 \mu \mathrm{g} /$ $\mathrm{L}$ at $\mathrm{pH}=8.5$, means are not computed and are plotted at $25 \mu \mathrm{g} / \mathrm{L}$ for visualization purposes for these conditions.

$\log$ (presumed to be in the exponential phase due to using nascent colonies from plate scrapes) in 90 min. ${ }^{16}$ Our data suggest that the transmissive form of Legionella, which is thought to exist outside of host organisms, can be more resistant to $\mathrm{Cu}$ than was previously understood.

Impact of $\mathrm{Cu}$ Concentration. To understand the $\mathrm{Cu}$ concentrations needed to reduce stationary phase L. pneumophila, three levels of $\mathrm{Cu}$ spanning biocidal level recommendations $(200,600$, and $800 \mu \mathrm{g} / \mathrm{L})$ were applied, with $\mathrm{pH}=7.0$ to maximize the concentration of $\mathrm{Cu}^{2+}$ (Figure 2). At a dose of $200 \mu \mathrm{g} / \mathrm{L}$ total $\mathrm{Cu}$, which yielded less than $10 \mu \mathrm{g} / \mathrm{L} \mathrm{Cu}^{2+}$ (Figures 1A and S6), there was only $\sim 1.5 \log$ reduction in $L$. pneumophila over $360 \mathrm{~min}$ as compared to $0.11 \mathrm{log}$ reduction in a control without added $\mathrm{Cu}$ (Figure 5). At $600-800 \mu \mathrm{g} / \mathrm{L}$ total $\mathrm{Cu}$, which were not significantly different $(p>0.05$ across all sampling points, ANOVA), where $\mathrm{Cu}^{2+}$ was $317.4-423.2$ $\mu \mathrm{g} / \mathrm{L}$ in the $\mathrm{Cu}$ speciation tests, L. pneumophila was reduced by up to $4 \log$ over $360 \mathrm{~min}$.

Impact of Cu Speciation. To analyze the effects of water chemistry on $\mathrm{Cu}$ inhibition of stationary L. pneumophila, 800 $\mu \mathrm{g} / \mathrm{L}$ total $\mathrm{Cu}$ was dosed to reactors at $\mathrm{pH}=7.0,7.5,8.0$, and
8.5. At $\mathrm{pH} 7$, parallel tests were conducted with 0.5 or $3.0 \mathrm{mg} /$ $\mathrm{L} \mathrm{PO}_{4}{ }^{3-}$ or $5 \mathrm{mg} / \mathrm{L} \mathrm{NOM}$ as TOC. Control experiments without any $\mathrm{Cu}$ dosing indicated $<0.7 \log \mathrm{CFU}$ reduction in all tested conditions over $360 \mathrm{~min}$ (Figure 6). As the $\mathrm{pH}$ increased from 7.0 to 8.5 , the log-reduction in Legionella CFUs at $t=360 \mathrm{~min}$ decreased from 3.65 to 1.34 (Figure 6). With the addition of $5 \mathrm{mg} / \mathrm{L} \mathrm{NOM}$, which is at the higher range of what is typical for drinking water, ${ }^{34}$ the toxicity of $\mathrm{Cu}$ was virtually eliminated (Figure 6), consistent with undetectable $\mathrm{Cu}^{2+}$ ions due to the formation of organic $\mathrm{Cu}$ ligands (Figure 3 ). With the addition of $0.5 \mathrm{mg} / \mathrm{L} \mathrm{PO}_{4}{ }^{3-}, \mathrm{Cu}$ was less biocidal than without phosphate, but it still reduced L. pneumophila by more than $2 \mathrm{log}$. At higher phosphate levels $\left(3 \mathrm{mg} / \mathrm{L} \mathrm{PO}_{4}{ }^{3-}\right)$, similar to the higher levels used in municipal drinking water systems for lead and $\mathrm{Cu}$ corrosion control, $\mathrm{Cu}$ only had a 1 log reduction in culturable Legionella and was not significantly different from the control ( $p$-value $=0.092$, ANOVA).

The negative effect of elevated $\mathrm{pH}$ on soluble $\mathrm{Cu}$ and toxicity toward Legionella has been demonstrated before with presumed exponential phase Legionella, but only at the two $\mathrm{pH}$ extremes of 7.0 and 9.0. ${ }^{10}$ Here, we demonstrate $\mathrm{Cu}$ toxicity toward stationary phase L. pneumophila, with finer granularity over this key $\mathrm{pH}$ range, demonstrating there is a gradual drop off of $\mathrm{Cu}$ toxicity as $\mathrm{Cu}$ is precipitated. In addition, previous work reported that $20 \mathrm{mg} / \mathrm{L}$ dissolved organic carbon was needed to eliminate $\mathrm{Cu}$ toxicity, suggesting that only unrealistic levels of organic matter for drinking water would likely impact $\mathrm{Cu}$ toxicity. ${ }^{10}$ However, here, we demonstrated that $5 \mathrm{mg} / \mathrm{L}$ organic carbon, at the higher range of what is typical for drinking water, ${ }^{34}$ can also nearly eliminate $\mathrm{Cu}$ toxicity. On the basis of the copper speciation results, it is reasonable to expect that even doses as low as $2 \mathrm{mg} / \mathrm{L} \mathrm{HA}$ or FA would have also reduced toxicity (Figure 3), in contrast to the prior study indicating no impact of $2 \mathrm{mg} / \mathrm{L}$ on $\mathrm{Cu}$ toxicity. ${ }^{10}$ It is possible that the higher hardness in the earlier work $\left(110 \mathrm{mg} / \mathrm{L}\right.$ as $\left.\mathrm{CaCO}_{3}\right)$ versus this work $(30 \mathrm{mg} / \mathrm{L}$ as $\left.\mathrm{CaCO}_{3}\right)$ maintained the antimicrobial effects of $\mathrm{Cu}^{2+}$ in the presence of $2 \mathrm{mg} / \mathrm{L}$. When we added $70 \mathrm{mg} / \mathrm{L}$ extra calcium hardness to our water with NOM, we observed a $>50 \%$ increase in $\mathrm{Cu}^{2+}$ levels in the water. Finally, we demonstrate for the first time that enhanced corrosion control, with the addition of phosphate-based corrosion inhibitors that complex $\mathrm{Cu}$, also reduces $\mathrm{Cu}$ toxicity by $3.9 \times$ at concentrations relevant to drinking water.

Estimating Cu Disinfection Coefficient. The ChickWatson model, $\ln \left(N_{t} / N_{0}\right)=k C t$, was used to calculate the $\mathrm{Cu}$ disinfection constant for the strain of L. pneumophila used in this study, $k\left(\mathrm{~L} \mu \mathrm{g}^{-1} \min ^{-1}\right)$, where $N_{t}$ is the average of three replicates of culturable $L$. pneumophila at time $t, N_{0}$ is the average initial culturable $L$. pneumophila at time $=0 \mathrm{~min}$, and $C$ is the biocidal copper concentration. Four forms of copper were considered for modeling the reduction in L. pneumophila: measured total $\mathrm{Cu}$, soluble $\mathrm{Cu}, \mathrm{Cu}^{2+}$, and inorganic soluble $\mathrm{Cu}$ (inorganic ligands complexed portion of soluble $\mathrm{Cu}$ ). The latter was estimated using thermodynamic equilibrium models based on the measured $\mathrm{Cu}^{2+}$, soluble $\mathrm{Cu}, \mathrm{pH}$, and published complexation constants for $\mathrm{Cu}(\mathrm{OH})^{+}$and $\mathrm{Cu}(\mathrm{OH})_{2}{ }^{0}$. We assumed that chloride $\mathrm{Cu}$ complexes were negligible in the base water used in this experiment (Table S2).

The $\mathrm{Cu}$ disinfection constant for L. pneumophila ranged

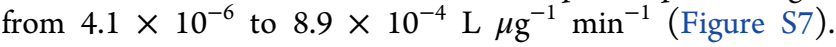
Despite 2 orders of magnitude variation, all estimates fit the 


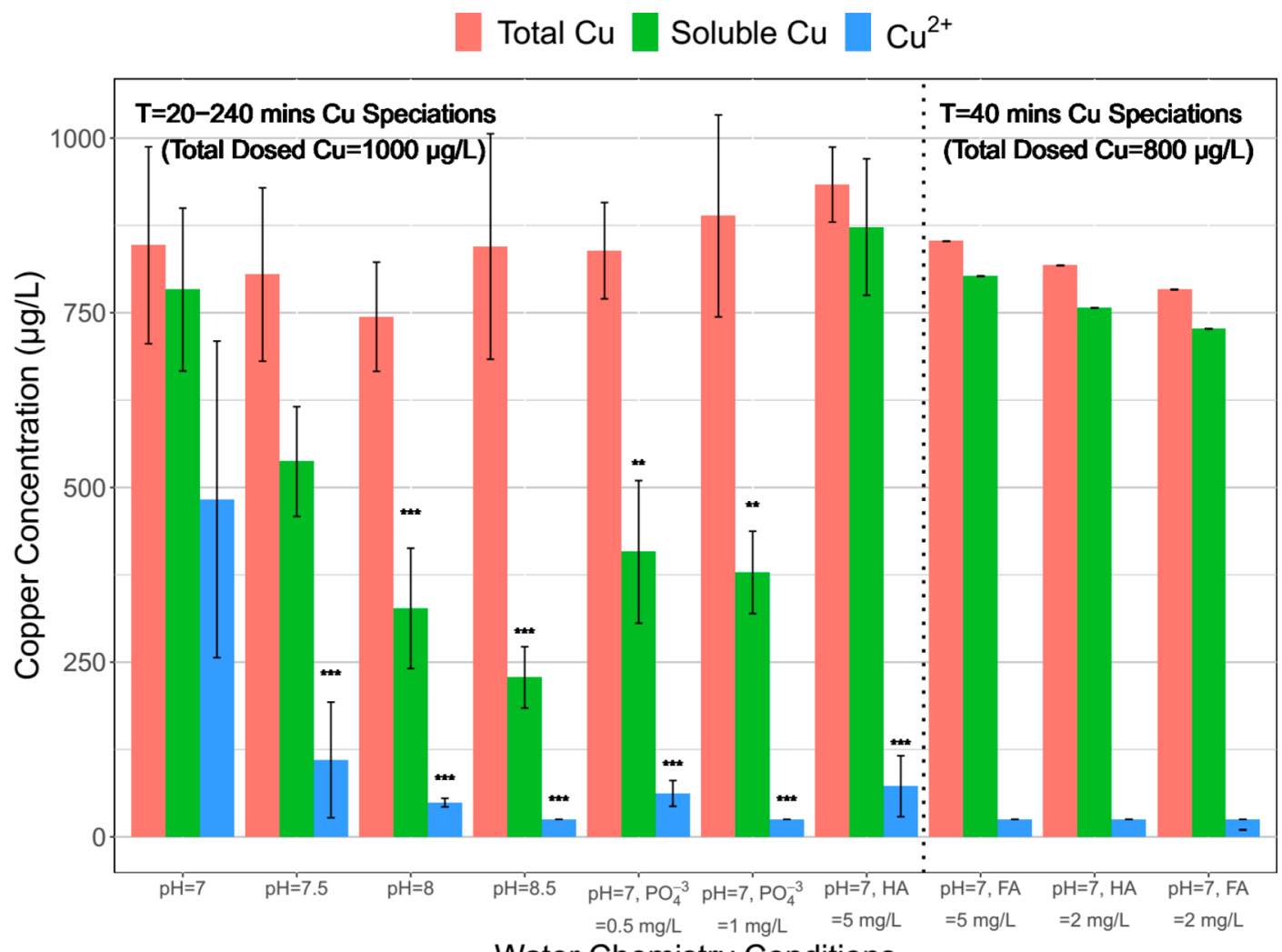

Figure 3. $\mathrm{Cu}$ speciation (total, soluble, and $\mathrm{Cu}^{2+}$ ) in base water at various $\mathrm{pH}$ values (7-8.5) and with addition of ligand-forming constituents $\left(\mathrm{PO}_{4}{ }^{3-}, \mathrm{NOM}\right.$ as humic acid (HA) or fulvic acid (FA)). For water chemistry conditions left of the dashed line, bars represent average and error bars represent standard deviation of triplicate independent reactors, including samples after $20-240$ min incubation. For the $\mathrm{pH}^{2}=8.5$ and $\mathrm{PO}_{4}{ }^{3-}$ dosing at $1 \mathrm{mg} / \mathrm{L}$ conditions, $\mathrm{Cu}^{2+}$ summary statistics were not computed due to the high amount of left-censored data (i.e., below the quantification limit of $50 \mu \mathrm{g} / \mathrm{L}$ ); therefore, the means are displayed at $25 \mu \mathrm{g} / \mathrm{L}$ for visualization purposes. Some loss of total Cu from target dose is due to attachment to the glass reactor at elevated $\mathrm{pH}$. The average soluble $\mathrm{Cu}$ or $\mathrm{Cu}^{2+}$ levels that were significantly different from those at $\mathrm{pH}=7$ are indicated above the corresponding bars in the charts (Kruskal-Wallis test with post hoc Dunn's test (Bonferroni correction) or regression by maximum likelihood estimation for left-censored data, “***” for $p<0.001$ and “**” for $p<0.01$ ). For water chemistry conditions to the right of the dashed line, the bars represent the results of one trial using total $\mathrm{Cu}=800 \mu \mathrm{g} / \mathrm{L}$ speciation with the indicated HA and FA doses to assess any potential differences between the two NOM sources after $40 \mathrm{~min}$ of incubation.

Chick-Watson model with $R^{2}>0.8$ for all conditions, except the condition with $5 \mathrm{mg} / \mathrm{L}$ NOM-as TOC $\left(R^{2}>0.5\right)$. This was likely due to $<0.6 \log _{10}$ reduction in $\mathrm{Cu}$ inactivation experiments and the large fraction of the soluble $\mathrm{Cu}$ existing as biounavailable organically bound $\mathrm{Cu}$. Across this wide range of $\mathrm{pH}$ values, phosphate, and NOM, inorganic soluble $\mathrm{Cu}$ was the best measure of the biocidal concentration of $\mathrm{Cu}$ species in these experiments, as indicated by the lowest RSD across conditions $(20.4 \%)$. The next best fit was soluble $\mathrm{Cu}$ (RSD = $44 \%)$, suggesting that in most drinking waters without significant amounts of organic matter, soluble $\mathrm{Cu}$ could be a good measure to predict the toxicity of $\mathrm{Cu}$.

Only at $\mathrm{pH}=8.5$, where both soluble $\mathrm{Cu}$ and $\mathrm{Cu}^{2+}$ were reduced by $69.7 \%$ and $>94.4 \%$, respectively, as compared to $\mathrm{pH} 7.0$, did the $\log \mathrm{CFU} / \mathrm{mL}$ reduction become significantly different relative to that at $\mathrm{pH}=7$ (Figure 6). The increase in $\mathrm{pH}$ from 7 to 7.5 , which can occur within a plumbing system, ${ }^{35}$ resulted in substantial reduction of $\mathrm{Cu}^{2+}$, but the $\log \mathrm{CFU} / \mathrm{mL}$ reductions were not significantly changed. This is attributed to (1) inherent variation of microbial resistance to heavy metals in replicates observed in this study (e.g., Figure 6); (2) other forms of soluble $\mathrm{Cu}$ besides $\mathrm{Cu}^{2+}$ (assumed to be $\mathrm{Cu}$ hydroxide species in this study) still exerting toxicity toward Legionella; and (3) reduction in competition for complexation of toxic forms of $\mathrm{Cu}$ between hydroxide ions and biomass. ${ }^{23}$ This clearly demonstrates that not all soluble $\mathrm{Cu}$ has the same biocidal capacity. In practical applications, only total and, in some instances (e.g., with high $\mathrm{NOM}$ ), soluble $\mathrm{Cu}$ can be misleading in terms of quantifying biocidal action because water chemistry can strongly influence $\mathrm{Cu}$ solubility via precipitation and complexation. ${ }^{21,36,37}$

Estimating the Chick-Watson model disinfectant coefficient from Lin et al.'s work, using soluble copper measured in their

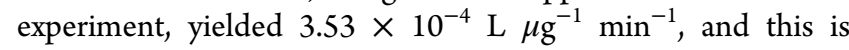
approximately 100 times higher than that estimated herein, resulting in much faster $\mathrm{Cu}$-induced $L$. pneumophila disinfection rates. Some key differences in experimental conditions likely contribute to this difference, including strains used $^{26}$ and life stage, as demonstrated herein. However, Lin et al. ${ }^{10}$ defined soluble $\mathrm{Cu}$ as that which remained in suspension after pelleting cells, which would represent an underestimate of $\mathrm{Cu}$ due to complexation with cell debris relative to the $0.45 \mu \mathrm{m}$ filter definition herein. With these key differences, in combination with natural biological variability, it is likely these disinfectant constants are not substantially different.

Total $\mathrm{Cu}$ and $\mathrm{Cu}^{2+}$ Trends among Drinking Water Utilities over the Last Three Decades. We compared reported 90th percentile $\mathrm{Cu}$ levels at 33 major drinking water 
L. pneumophila 130b Log CFU Reduction ( $\mathrm{pH}=7.0)$

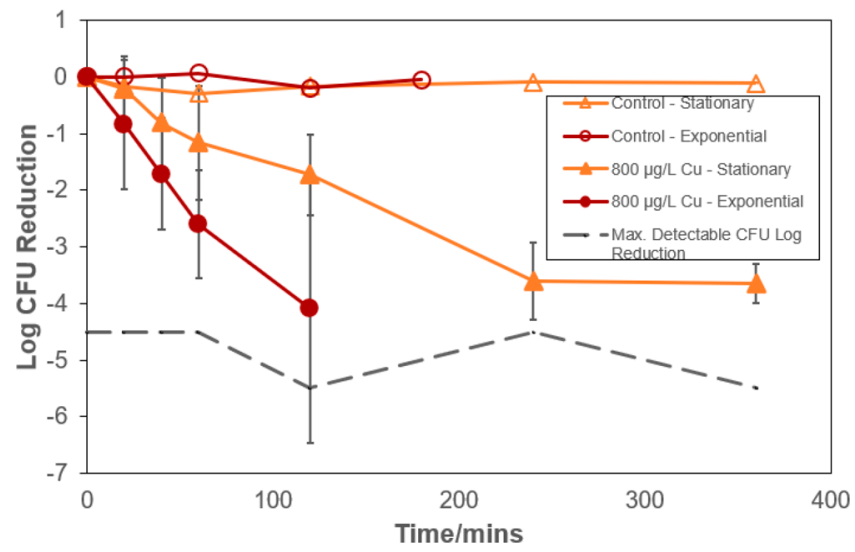

Figure 4. L. pneumophila log reduction in CFU for exponential phase and early stationary growth phase with and without $800 \mu \mathrm{g} / \mathrm{L} \mathrm{Cu}$ at $\mathrm{pH}=7$. Data points and error bars represent the average and standard deviation of triplicate independent sacrificial inactivation reactors. Control shows one trial, measured over several time points to demonstrate stability during the experiment. Dashed line represents the maximum measurable log reduction based on the lower LOD, which varies at each time point according to the plate dilutions applied.

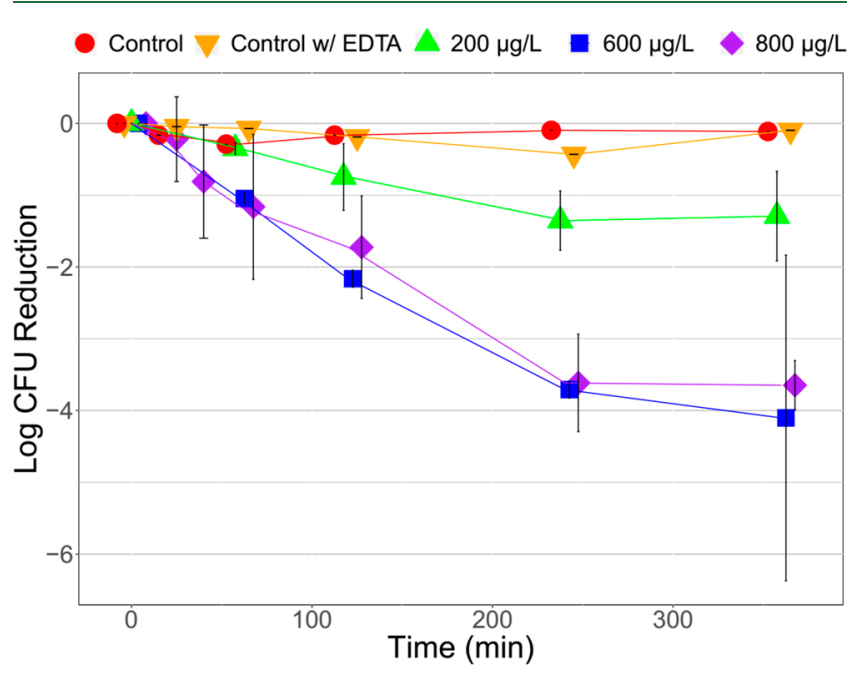

Figure 5. Early stationary L. pneumophila log reduction with different $\mathrm{Cu}$ doses as a function of time at $\mathrm{pH}=7$. Data points and error bars represent the average and standard deviation of triplicate independently sacrificed inactivation reactors. "Control" and "Control w/EDTA" were not dosed with $\mathrm{Cu}$, with one trial for each, measured over several time points, to demonstrate stability in the control conditions.

utilities in $1990^{32}$ to the most recent data for the same utilities in 2018 in publicly available consumer confidence reports. As expected, given that $\mathrm{Cu}$ pipes aged and corrosion control efficacy has improved, the average 90th percentile total $\mathrm{Cu}$ levels have decreased in more than $90 \%$ (30 of 33) of utilities surveyed, from an average of $477 \mu \mathrm{g} / \mathrm{L}$ in 1990 to $223 \mu \mathrm{g} / \mathrm{L}$ in 2018 (Figure 7). Out of 33 surveyed utilities, 11 had data on phosphate, $\mathrm{pH}$, and alkalinity available to predict $\mathrm{Cu}^{2+}$ levels in both 1990 and 2018 using MINEQL+ software with the assumption that all 90th percentile copper was soluble. ${ }^{37,38}$ Overall, results from 1990 indicated a range of predicted $\mathrm{Cu}^{2+}$, from 0 to $293 \mu \mathrm{g} / \mathrm{L}$, with a median level of $11 \mu \mathrm{g} / \mathrm{L}$ (Figure 7). The 2018 results indicated a range of $\mathrm{Cu}^{2+}$ from 0 to $54 \mu \mathrm{g} / \mathrm{L}$

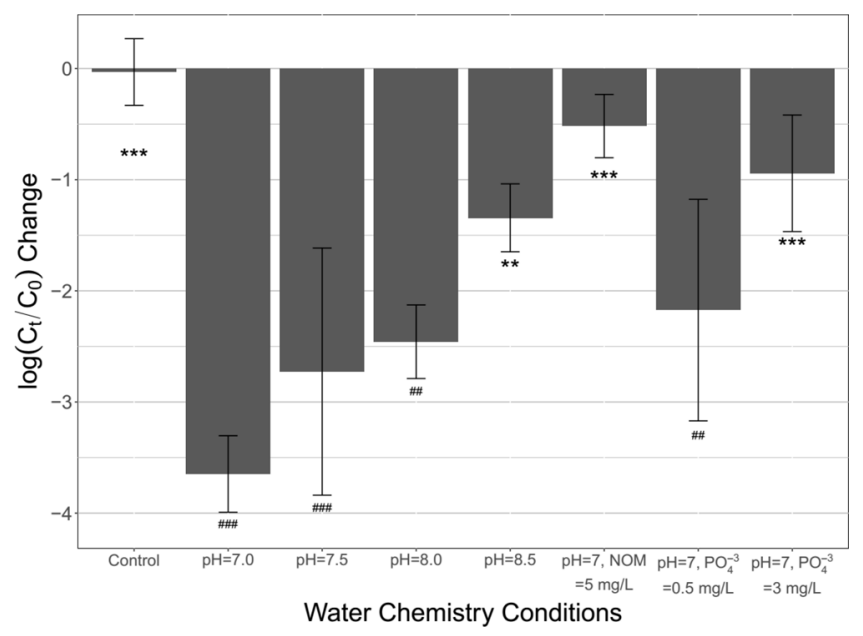

Figure 6. Log reduction in early stationary phase L. pneumophila after $6 \mathrm{~h}$ of incubation under the indicated water chemistry conditions. Control group combines measurements without $\mathrm{Cu}$ at $\mathrm{pH}=7,7.5,8$, and $8.5, \mathrm{PO}_{4}{ }^{3-}=3 \mathrm{mg} / \mathrm{L}$, and $\mathrm{NOM}=5 \mathrm{mg} / \mathrm{L}$ as TOC (13 replicates total; 3 from $\mathrm{pH}=7$ and $8.5 ; 2$ from $\mathrm{PO}_{4}{ }^{3-}=3 \mathrm{mg} / \mathrm{L}$ and $\mathrm{NOM}=5$ $\mathrm{mg} / \mathrm{L}$; and 1 from $\mathrm{pH}=7.5$ and 8 and $\mathrm{PO}_{4}{ }^{3-}=0.5 \mathrm{mg} / \mathrm{L}$ ). Bars and error bars represent the average and standard deviation of 13 replicates (control) and triplicate (in $\mathrm{Cu}$ inactivation) samples. The average $\log \left(C_{t} / C_{0}\right)$ reduction values that were significantly different from those of the $\mathrm{pH}=7$ condition (ANOVA test, “***” for $p<$ 0.001 ; “**" for $p<0.01$ ) and the control condition (ANOVA test, “\#\#”” for $p<0.001$; “\#\#” for $p<0.01)$ are labeled below the bars.

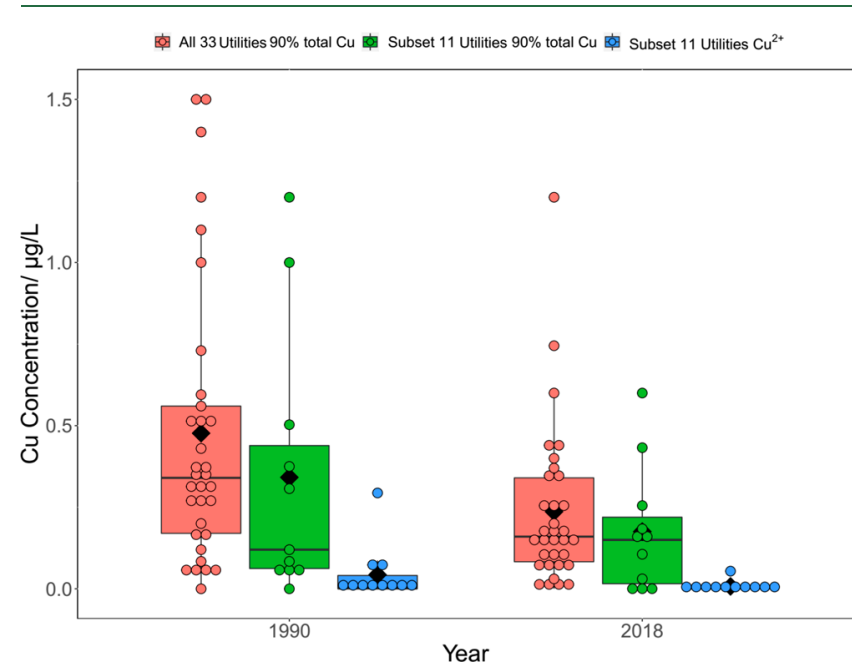

Figure 7. Total $\mathrm{Cu}$ (90th percentile) extracted from Consumer Confidence Reports of 33 major drinking water utilities from 1990 and 2018. Total $\mathrm{Cu}$ (90th percentile) and estimated $\mathrm{Cu}^{2+}$ of a subset of 11 utilities for thermodynamic equilibrium models. Boxplots represent the interquartile range (IQR), while whiskers represent a deviation of $\pm 1.5^{*} \mathrm{IQR}$ from the median. Solid diamonds represent mean $\mathrm{Cu}$ concentrations.

and a median level of $1 \mu \mathrm{g} / \mathrm{L}$. This analysis confirms that characteristic $\mathrm{Cu}^{2+}$ levels likely decreased more dramatically $(>10 \times)$ than did total or soluble $\mathrm{Cu}(2 \times)$. This is a potential contributing factor that has not previously been suggested related to increasing incidence of Legionnaires' disease, even though $\mathrm{Cu}$ pipes are the primary material used in commercial buildings. Other potentially prominent factors thought to contribute to increasing rates of Legionnaires' disease include 
improved diagnosis and reporting, aging of the national water infrastructure, and an aging population. ${ }^{39}$

\section{IMPLICATIONS}

On the basis of the results presented herein, to achieve at least a 2 log reduction in bulk water L. pneumophila in $6 \mathrm{~h}$, it would be necessary to maintain a level of copper inorganic complexes at about $600 \mu \mathrm{g} / \mathrm{L}$. While passive control of L. pneumophila has been documented, the increased use of phosphate-based corrosion control has decreased baseline levels of $\mathrm{Cu}$ in drinking water systems down to an average 90th percentile $\mathrm{Cu}$ of $\sim 250 \mu \mathrm{g} / \mathrm{L}$. The increased phosphate dose also likely disproportionately decreased the forms of soluble $\mathrm{Cu}$ that are most biocidal (Figures 6 and 7). For CSI systems, EPA and WHO recommend regular monitoring of total $\mathrm{Cu}$ levels, ${ }^{3,40}$ and published studies suggest that $200-800 \mu \mathrm{g} / \mathrm{L}$ for $\mathrm{Cu}$ and $10-80 \mu \mathrm{g} / \mathrm{L}$ for silver will be effective. ${ }^{3,14-16}$ Our results demonstrated that these levels would not be sufficient for a wide range of relevant conditions, including higher $\mathrm{pH}$, high levels of NOM, or the presence of orthophosphate corrosion inhibitors, at least for copper alone. ${ }^{16}$ This study also helps explain noted discrepancies in the observed effects of copper on Legionella reported in the literature. ${ }^{7,9-12}$ In practice, to balance corrosion inhibition and counter other water chemistry effects on $\mathrm{Cu}$ biocidal efficacy, in-building water chemistry adjustment and other applicable L. pneumophila control technologies should be considered. At a minimum, those implementing CSI should measure soluble $\mathrm{Cu}$ and organic carbon. Organic carbon concentrations in the range of $2-5$ $\mathrm{mg} / \mathrm{L}$ are at higher risk of decreasing $\mathrm{Cu}$ biocidal efficacy. ${ }^{10}$ Here, we focus only on the effect of copper ions. Follow-up research on silver ions, which have been demonstrated to have synergistic antimicrobial effects with copper, would also be of value. $^{16}$

Other factors not examined in this study are also likely to impact $\mathrm{Cu}$ toxicity, such as Legionella strain. Recently, an up to 4-fold variation in the susceptibility to cupric chloride was reported among various environmental strains of Legionella tested. $^{26}$ In addition, exposure to $\mathrm{Cu}$ may induce viable but nonculturable (VBNC) Legionella that may regrow once the external stress (i.e., $\mathrm{Cu}$ ) is removed or changes in conditions encourage their growth (e.g., amoeba host), as has been demonstrated with other biocides, but not with $\mathrm{Cu}^{41-44}$ Finally, Legionella residing within amoeba hosts and/or biofilms would likely require higher levels of $\mathrm{Cu}$ to be inactivated than indicated in this work, as the amoebae serve as an additional barrier to exposure to biocidal levels of $\mathrm{Cu}^{45}$ and $\mathrm{Cu}$ may form organic complexes with biomass, reducing its biocidal capacity. Such factors require additional research.

\section{ASSOCIATED CONTENT}

\section{SI Supporting Information}

The Supporting Information is available free of charge at https://pubs.acs.org/doi/10.1021/acs.est.0c06804.

Figure S1, Copper stability bench-scale testing workflow; Figure S2, Copper speciation bench-scale testing workflow; Figure S3, Measured copper concentration comparison between inductively coupled plasma mass spectrometry (ICP-MS) and HACH Method 8506; Figure S4, Cupric ion selective probe relative standard deviation changes as a function of total copper levels; Figure S5, L. pneumophila strain 130 b growth curve;
Figure S6, Copper inactivation bench-scale tests workflow; Figure S7, Disinfection rate $k$ comparison across different water chemistry conditions using disinfectants as $\mathrm{Cu}^{2+}$, soluble $\mathrm{Cu}$, inorganic soluble $\mathrm{Cu}$, and total $\mathrm{Cu}$; Table S1, Typical base water characters before and after three filter treatments; and Table S2, MINEQL+ model of representative base water conditions $(\mathrm{pH}=7$, alkalinity $=40 \mathrm{mg} / \mathrm{L})$ predicting $\mathrm{Cu}(800 \mu \mathrm{g} / \mathrm{L}$ or $1.25 \times 10^{-5} \mathrm{M}$ ) species at equilibrium (assuming no solids' formation to represent short-term steady state) (PDF)

\section{AUTHOR INFORMATION}

\section{Corresponding Authors}

Marc A. Edwards - Civil and Environmental Engineering, Virginia Tech, Blacksburg, Virginia 24061, United States; (1) orcid.org/0000-0002-1889-1193; Phone: (540) 2317236; Email: edwardsm@vt.edu; Fax: (540) 231-7916

William J. Rhoads - Civil and Environmental Engineering, Virginia Tech, Blacksburg, Virginia 24061, United States; Swiss Federal Institute of Aquatic Science and Technology, Dübendorf 8600, Switzerland; (1) orcid.org/0000-00019325-4680; Email: wrhoads@vt.edu

\section{Authors}

Yang Song - Civil and Environmental Engineering, Virginia Tech, Blacksburg, Virginia 24061, United States; (1) orcid.org/0000-0002-3040-0414

Amy Pruden - Civil and Environmental Engineering, Virginia Tech, Blacksburg, Virginia 24061, United States;

(1) orcid.org/0000-0002-3191-6244

Complete contact information is available at:

https://pubs.acs.org/10.1021/acs.est.0c06804

\section{Author Contributions}

M.A.E., W.J.R., and Y.S. designed the experiments and assisted in the analysis of results. Y.S. conducted the experiments and prepared the first draft of the manuscript. A.P. was a co-PI on the NSF grant and provided feedback on the experimental design and analysis of the results. All authors contributed to the writing of the manuscript and approved the final version.

Notes

The authors declare no competing financial interest.

\section{ACKNOWLEDGMENTS}

This work was funded by the National Science Foundation (NSF) \#1706733 and the Virginia Tech Institute for Critical Technology and Applied Science. NSF NNCI Award 1542100 further provided lab resources for this research. The views expressed are those of the authors and not necessarily those of the NSF. We acknowledge the professional consultation support of Adam Estelle from the Copper Development Association. We appreciate Dr. Jeffrey Parks and Jody Smiley for analytical measurement support and Carol Yang for her contribution to the lab work.

\section{REFERENCES}

(1) Legionnaires Disease History and Patterns. Legionella; CDC; https://www.cdc.gov/legionella/about/history.html (accessed Oct 31, 2019).

(2) National Academies of Sciences, Engineering, and Medicine. Management of Legionella in Water Systems; National Academies Press: Washington, DC, February 20, 2020. 
(3) U.S. EPA. Technologies for Legionella Control in Premise Plumbing Systems; https://www.epa.gov/ground-water-and-drinkingwater/technologies-legionella-control-premise-plumbing-systems (accessed Oct 31, 2019).

(4) Association of State Drinking Water Administrators. State Approaches to Building Water System Regulation. ASDWA; September, 2019.

(5) Liu, Z.; Stout, J. E.; Tedesco, L.; Boldin, M.; Hwang, C.; Diven, W. F.; Yu, V. L. Controlled Evaluation of Copper-Silver Ionization in Eradicating Legionella pneumophila from a Hospital Water Distribution System. J. Infect. Dis. 1994, 169 (4), 919-922.

(6) Rohr, U.; Senger, M.; Selenka, F.; Turley, R.; Wilhelm, M. Four Years of Experience with Silver-Copper Ionization for Control of Legionella in a German University Hospital Hot Water Plumbing System. Clin. Infect. Dis. 1999, 29 (6), 1507-1511.

(7) Walraven, N.; Pool, W.; Chapman, C. Efficacy of Copper-Silver Ionization in Controlling Legionella in Complex Water Distribution Systems and a Cooling Tower: Over 5 Years of Practical Experience. Journal of Water Process Engineering 2016, 13, 196-205.

(8) Triantafyllidou, S.; Lytle, D.; Muhlen, C.; Swertfeger, J. CopperSilver Ionization at a US Hospital: Interaction of Treated Drinking Water with Plumbing Materials, Aesthetics and Other Considerations. Water Res. 2016, 102, 1-10.

(9) Stout, J. E.; Yu, V. L. Experiences of the First 16 Hospitals Using Copper-Silver Ionization for Legionella Control: Implications for the Evaluation of Other Disinfection Modalities. Infection Control \& Hospital Epidemiology 2003, 24 (8), 563-568.

(10) Lin, Y.-S. E.; Vidic, R. D.; Stout, J. E.; Yu, V. L. Negative Effect of High $\mathrm{pH}$ on Biocidal Efficacy of Copper and Silver Ions in Controlling Legionella pneumophila. Appl. Environ. Microbiol. 2002, 68 (6), 2711-2715.

(11) Mathys, W.; Stanke, J.; Harmuth, M.; Junge-Mathys, E. Occurrence of Legionella in Hot Water Systems of Single-Family Residences in Suburbs of Two German Cities with Special Reference to Solar and District Heating. Int. J. Hyg. Environ. Health 2008, 211 (1), 179-185.

(12) Cullom, A. C.; Martin, R. L.; Song, Y.; Williams, K.; Williams, A.; Pruden, A.; Edwards, M. A. Critical Review: Propensity of Premise Plumbing Pipe Materials to Enhance or Diminish Growth of Legionella and Other Opportunistic Pathogens. Pathogens 2020, 9 (11), 957.

(13) Hans, M.; Erbe, A.; Mathews, S.; Chen, Y.; Solioz, M.; Mücklich, F. Role of Copper Oxides in Contact Killing of Bacteria. Langmuir 2013, 29 (52), 16160-16166.

(14) Cachafeiro, S. P.; Naveira, I. M.; García, I. G. Is Copper-Silver Ionization Safe and Effective in Controlling Legionella? Journal of Hospital Infection 2007, 67 (3), 209-216.

(15) Miuetzner, S.; Schwille Robert, C.; Farley, A.; Wald, E. R.; Ge, J. H.; States, S. J.; Libert, T.; Wadowsky, R. M. Efficacy of Thermal Treatment and Copper-Silver Ionization for Controlling Legionella pneumophila in High-Volume Hot Water Plumbing Systems in Hospitals. Am. J. Infect. Control 1997, 25 (6), 452-457.

(16) Lin, Y.-S. E.; Vidic, R. D.; Stout, J. E.; Yu, V. L. Individual and Combined Effects of Copper and Silver Ions on Inactivation of Legionella pneumophila. Water Res. 1996, 30 (8), 1905-1913.

(17) Zevenhuizen, L. P. T. M.; Dolfing, J.; Eshuis, E. J.; ScholtenKoerselman, I. J. Inhibitory Effects of Copper on Bacteria Related to the Free Ion Concentration. Microb. Ecol. 1979, 5 (2), 139-146.

(18) Lytle, D. A.; Liggett, J. Impact of Water Quality on Chlorine Demand of Corroding Copper. Water Res. 2016, 92, 11-21.

(19) Anderson, L. E.; Krkocek, W. H.; Stoddart, A. K.; Trueman, B. F.; Gagnon, G. A. Lake Recovery Through Reduced Sulfate Deposition: A New Paradigm for Drinking Water Treatment. Environ. Sci. Technol. 2017, 51 (3), 1414-1422.

(20) Eikebrokk, B.; Vogt, R. D.; Liltved, H. NOM Increase in Northern European Source Waters: Discussion of Possible Causes and Impacts on Coagulation/Contact Filtration Processes. Water Sci. Technol.: Water Supply 2004, 4 (4), 47-54.
(21) Edwards, M.; Ferguson, J. F.; Reiber, S. H. The Pitting Corrosion of Copper. J. - Am. Water Works Assoc. 1994, 86 (7), 7490.

(22) Edwards, M.; Sprague, N. Organic Matter and Copper Corrosion by-Product Release: A Mechanistic Study. Corros. Sci. 2001, 43 (1), 1-18.

(23) Meador, J. P. The Interaction of $\mathrm{pH}$, Dissolved Organic Carbon, and Total Copper in the Determination of Ionic Copper and Toxicity. Aquat. Toxicol. 1991, 19 (1), 13-31.

(24) Garvey, J. E.; Owen, H. A.; Winner, R. W. Toxicity of Copper to the Green Alga, Chlamydomonas reinhardtii (Chlorophyceae), as Affected by Humic Substances of Terrestrial and Freshwater Origin. Aquat. Toxicol. 1991, 19 (2), 89-96.

(25) Molofsky, A. B.; Swanson, M. S. Differentiate to Thrive: Lessons from the Legionella pneumophila Life Cycle. Mol. Microbiol. 2004, 53 (1), 29-40.

(26) Bédard, E.; Paranjape, K.; Lalancette, C.; Villion, M.; Quach, C.; Laferrière, C.; Faucher, S. P.; Prévost, M. Legionella pneumophila Levels and Sequence-Type Distribution in Hospital Hot Water Samples from Faucets to Connecting Pipes. Water Res. 2019, 156, 277-286.

(27) Brazeau, R. H.; Edwards, M. A. Role of Hot Water System Design on Factors Influential to Pathogen Regrowth: Temperature, Chlorine Residual, Hydrogen Evolution, and Sediment. Environ. Eng. Sci. 2013, 30 (10), 617-627.

(28) Rhoads, W. J.; Pruden, A.; Edwards, M. A. Convective Mixing in Distal Pipes Exacerbates Legionella pneumophila Growth in Hot Water Plumbing. Pathogens 2016, 5 (1), 29.

(29) Zhang, Y. Relative Effects of Water Chemistry on Aspects of Iron Corrosion. Thesis, Virginia Tech, 2005.

(30) Cole-Parmer Instrument Company. Cole-Parmer Laboratory Cuppric Ion Electrode Instruction Manual; Cole-Parmer Instrument Company.

(31) Weinstein, M.; Patel, J. M07: Methods for Dilution AST for Aerobically Grown Bacteria - CLSI; https://clsi.org/standards/ products/microbiology/documents/m07/ (accessed Oct 31, 2019).

(32) Dodrill, D. M.; Edwards, M. Corrosion Control on the Basis of Utility Experience. J. - Am. Water Works Assoc. 1995, 87 (7), 74-85.

(33) U.S. EPA. Nonpoint Source Monitoring: TechNOTES; https://www.epa.gov/nps/nonpoint-source-monitoring-technotes (accessed Dec 2, 2020).

(34) Volk, C.; Bell, K.; Ibrahim, E.; Verges, D.; Amy, G.; LeChevallier, M. Impact of Enhanced and Optimized Coagulation on Removal of Organic Matter and Its Biodegradable Fraction in Drinking Water. Water Res. 2000, 34 (12), 3247-3257.

(35) DeBerry, D.; Kidwell, J.; Malish, D. Corrosion in Potable Water Systems: Final Report; https://nepis.epa.gov/Exe/ZyNET.exe/ 9100CILD.txt ZyActionD=ZyDocument $\&$ Client=EPA\&Index $=$ $1981 \% 20 \mathrm{Thru} \% 201985 \&$ Docs $=\&$ Query $=\&$ Time $=\&$ EndTime $=$ $\&$ SearchMethod $=1 \&$ TocRestrict $=$ n\&Toc $=\&$ TocEntry $=\&$ QField $=$ $\&$ QFieldYear $=\&$ QFieldMonth $=\&$ QFieldDay $=\&$ UseQField $=$ \&IntQField Op $=0 \&$ ExtQField $O p=0 \& X m l Q u$ ery $=\&$ File $=$ D \% 3 A \% 5 C Z Y F I L E S \% 5 C IN D E X \% 20 D A T A \% 5 C 81 THRU 85\%5CTXT\%5C00000016\%5C9100CILD.txt\&User= ANONYMOUS\&Password =anonymous\&SortMethod $=\mathrm{h} \% 7 \mathrm{C}$ \&MaximumDocuments $=1 \&$ FuzzyDegree $=0$ \&Image Quality $=r 75 \mathrm{~g} 8 /$ r75g8/x150y150g16/i425\&Display $=$ hpfr \&DefSeekPage $=$ $\mathrm{x} \&$ SearchBack $=$ ZyAction $L \& B$ ack $=$ ZyAction $S \& B$ ackDesc $=$ Results\%20page\&MaximumPages $=1 \& Z y$ Entry=5 (accessed Aug 24, 2020).

(36) Edwards, M.; Schock, M. R.; Meyer, T. E. Alkalinity, pH, and Copper Corrosion by-Product Release. J. - Am. Water Works Assoc. 1996, 88 (3), 81-94.

(37) Schock, M. R.; Lytle, D. A.; Clement, J. A. Effect of pH, DIC, orthophosphate and sulfate on drinking water cuprosolvency; https:// www.osti.gov/biblio/128476 (accessed Mar 9, 2020).

(38) Edwards, M.; Hidmi, L.; Gladwell, D. Phosphate Inhibition of Soluble Copper Corrosion by-Product Release. Corros. Sci. 2002, 44 (5), 1057-1071. 
(39) Falconi, T. M. A.; Cruz, M. S.; Naumova, E. N. The Shift in Seasonality of Legionellosis in the U.S. Epidemiol. Infect. 2018, 146 (14), 1824-1833.

(40) WHO. Legionella and the prevention of legionellosis; http:// www.who.int/water_sanitation_health/publications/legionella/en/ (accessed Nov 2, 2019).

(41) Dietersdorfer, E.; Kirschner, A.; Schrammel, B.; OhradanovaRepic, A.; Stockinger, H.; Sommer, R.; Walochnik, J.; Cervero-Aragó, S. Starved Viable but Non-Culturable (VBNC) Legionella Strains Can Infect and Replicate in Amoebae and Human Macrophages. Water Res. 2018, 141, 428-438.

(42) Alleron, L.; Merlet, N.; Lacombe, C.; Frère, J. Long-Term Survival of Legionella pneumophila in the Viable But Nonculturable State After Monochloramine Treatment. Curr. Microbiol. 2008, 57 (5), 497-502.

(43) Mustapha, P.; Epalle, T.; Allegra, S.; Girardot, F.; Garraud, O.; Riffard, S. Monitoring of Legionella pneumophila Viability after Chlorine Dioxide Treatment Using Flow Cytometry. Res. Microbiol. 2015, 166 (3), 215-219.

(44) Grossi, M. R.; Dey, R.; Ashbolt, N. J. Searching for Activity Markers That Approximate (VBNC) Legionella pneumophila Infectivity in Amoeba after Ultraviolet (UV) Irradiation. Water 2018, 10 (9), 1219.

(45) Borella, P.; Guerrieri, E.; Marchesi, I.; Bondi, M.; Messi, P. Water Ecology of Legionella and Protozoan: Environmental and Public Health Perspectives. Biotechnology Annual Review; Elsevier: New York, 2005; Vol. 11, pp 355-380. 